\title{
Photosynthesis and Rubisco kinetics in spring wheat and meadow fescue under conditions of simulated climate change with elevated $\mathrm{CO}_{2}$ and increased temperatures
}

\author{
Kaija Hakala, Riitta Heliö \\ Agricultural Research Centre of Finland, Plant Production Research, FIN-31600 Jokioinen, Finland, \\ e-mail: kaija.hakala@mtt.fi \\ Eeva Tuhkanen \\ Finnish Forest Research Institute, Suonenjoki Research Station, FIN-97600 Suonenjoki, Finland \\ Timo Kaukoranta \\ Agricultural Research Centre of Finland, Plant Production Research, FIN-31600 Jokioinen, Finland
}

\begin{abstract}
Spring wheat (Triticum aestivum L. cv. Polkka) and meadow fescue (Festuca pratensis Hudson cv. Kalevi) were grown in ambient and elevated $\left(700 \mu 11^{-1}\right)$ carbon dioxide concentration both at present ambient temperatures and at temperatures $3^{\circ} \mathrm{C}$ higher than at present simulating a future climate. The $\mathrm{CO}_{2}$ concentrations were elevated in large ( $3 \mathrm{~m}$ in diameter) open top chambers and the temperatures in a greenhouse built over the experimental field. The photosynthetic rate of both wheat and meadow fescue was $31-37 \%$ higher in elevated carbon dioxide $\left(\mathrm{eCO}_{2}\right)$ than in ambient $\mathrm{CO}_{2}\left(\mathrm{aCO}_{2}\right)$ throughout the growing season. The enhancement in wheat photosynthesis in $\mathrm{eCO}_{2}$ declined 10-13 days before yellow ripeness, at which point the rate of photosynthesis in both $\mathrm{CO}_{2}$ treatments declined. The stomatal conductance of wheat and meadow fescue was $23-36 \%$ lower in $\mathrm{eCO}_{2}$ than in $\mathrm{aCO}_{2}$. The amount and activity of ribulose-1,5-bisphosphate carboxylase-oxygenase (Rubisco) in wheat were lower under conditions of $\mathrm{eCO}_{2}$, except at elevated temperatures in 1993 when there was a clear yield increase. There was no clear change in the amount and activity of Rubisco in meadow fescue under $\mathrm{eCO}_{2}$ at either elevated or ambient temperature. This suggests that adaptation to elevated $\mathrm{CO}_{2}$ at biochemical level occurs only when there is insufficient sink for photosynthetic products. While the sink size of wheat can be increased only by introducing new, more productive genotypes, the sink size of meadow fescue can be regulated by fitting the cutting schedule to growth.
\end{abstract}

Key words: carbon dioxide, Festuca pratensis, field-sown, open top chamber, Triticum aestivum

\section{Introduction}

The mean global atmospheric concentration of carbon dioxide $\left(\mathrm{CO}_{2}\right)$ has risen from about
$270 \mu 11^{-1}$ in pre-industrial times to almost 360 $\mu 11^{-1}$ (figure for 1994, IPCC 1996). In the most extreme scenario, it has been predicted that the concentration will increase up to $850 \mu \mathrm{l} \mathrm{l}^{-1}$ by the year 2100 (Carter 1996). Increases in $\mathrm{CO}_{2}$ 


\section{AGRICULTURAL AND FOOD SCIENCE IN FINLAND}

\section{Hakala, K. et al. Photosynthesis and Rubisco kinetics under conditions of climate change}

concentration, together with other changes in atmospheric composition, will significantly affect the global climate (IPCC 1996). Recent projections for Finland indicate a mean annual warming of 1.1 to $6.6^{\circ} \mathrm{C}$ by 2100 , with an average estimate of $4.4^{\circ} \mathrm{C}$ (Carter 1996).

The ambient concentration of $\mathrm{CO}_{2}$ in the present atmosphere is not high enough to saturate ribulose-1,5-bisphophate carboxylase-oxygenase (Rubisco), the enzyme responsible for the carboxylation reaction of photosynthesis. As much as 20-25\% of carbon assimilated is lost in photorespiration (Bowes 1991). All commonly cultivated crop plants in Finland are $\mathrm{C}_{3}$-plants, and thus subject to losses of assimilated carbon through photorespiration. Increase in the atmospheric $\mathrm{CO}_{2}$ concentration should therefore be beneficial for the photosynthesis and growth of Finnish crop plants.

When $\mathrm{CO}_{2}$ assimilation becomes more effective in elevated $\mathrm{CO}_{2}$, the Rubisco and protein concentrations in the leaves often are reduced (Schmitt and Edwards 1981, Bowes 1991, Hocking and Meyer 1991, Sage 1994, Nie et al. 1995, Rogers et al. 1998), and the stomatal conductance decreases (Bowes 1991, Conroy et al. 1994, Sage 1994, Pearson et al. 1995). With a concomitant increase in photosynthesis, the efficiency of both nitrogen use and water use increases (Wong 1979, Schmitt and Edwards 1981, Bowes 1991, Hocking and Meyer 1991). Decrease in the content of Rubisco protein of plants grown in elevated $\mathrm{CO}_{2}$ may decrease their photosynthetic capacity and thus limit their photosynthesis if $\mathrm{CO}_{2}$ levels become lower again (Sage et al. 1989, Sage 1994). Decrease in Rubisco content may nevertheless be important in the acclimation of plants to elevated $\mathrm{CO}_{2}$. A decrease in the amount of nitrogen fixed in Rubisco would make more nitrogen available for investment in processes limiting photosynthesis, e.g light harvesting complexes and electron transport (Quick et al. 1992, Sage 1994), or in enzymes involved in regeneration of ribulose-1,5-bisphosphate (RuBP) (Rogers et al. 1998). Nitrogen released from Rubisco might also be used in sink growth and thus diminish the limitation of photosynthe- sis caused by insufficient sink demand (Sharkey 1985, Stitt 1991, Rogers et al. 1998).

Rubisco makes up about $50 \%$ of the total soluble protein of plant leaves (Lawlor et al. 1989, Leegood 1993). Because a considerable part of the nitrogen of wheat leaves is used as a source of nitrogen for the grain (Dalling et al. 1976, Waters et al. 1980, Lawlor et al. 1989, Palta and Fillery 1995), a decrease in Rubisco and thus protein content in the leaves might decrease the protein content of the grain and the baking quality of the flour milled from it. Similarly, a decrease in the nitrogen content of grasses like meadow fescue might decrease the nutritional value of their biomass as animal feed.

The present study was undertaken to determine to what extent the photosynthesis of crop plants commonly cultivated in Finland is enhanced by elevated $\mathrm{CO}_{2}$ in field conditions, both at ambient temperatures and in conditions simulating the future warmer climate with average temperatures $3^{\circ} \mathrm{C}$ higher than at present. The content and activity of Rubisco in the leaves were studied in order to find out if biochemical acclimation to elevated $\mathrm{CO}_{2}$ will take place in fieldsown wheat and meadow fescue. The experiments were conducted during four growing seasons, in the years 1992-1995.

\section{Material and methods}

Spring wheat (Triticum aestivum L.) cv. Polkka and meadow fescue (Festuca pratensis Hudson) $\mathrm{cv}$. Kalevi were grown in the field at Jokioinen, southern Finland $\left(60^{\circ} 49^{\prime} \mathrm{N}, 23^{\circ} 30^{\prime} \mathrm{E}\right)$. The stands were subjected to four treatment conditions: a) ambient air temperature and ambient $\mathrm{CO}_{2}$ concentration; $b)$ increased temperature $\left(3^{\circ} \mathrm{C}\right.$ above ambient) and ambient $\mathrm{CO}_{2}$; c) ambient temperature and elevated $\mathrm{CO}_{2}\left(700 \mu \mathrm{ll}^{-1}\right)$ and d) increased temperature and elevated $\mathrm{CO}_{2}$. The sowing density of wheat was 500-600 germinating seeds $\mathrm{m}^{-2}$ (row width $12.5 \mathrm{~cm}$ ) in 1992-1994, 
Vol. 8 (1999): 441-457.

and 300 germinating seeds $\mathrm{m}^{-2}$ (row width 18.5 $\mathrm{cm})$ in 1995. Meadow fescue was sown twice, in 1992 (experiment 1) and in 1994 (experiment 2). The sowing density was 1250 germinating seeds $\mathrm{m}^{-2}$ in 1992 and 750 germinating seeds $\mathrm{m}^{-}$ ${ }^{2}$ in 1994 (row width $12.5 \mathrm{~cm}$ ). For meadow fescue, the years 1993 and 1995 were the second, or main yield production growing seasons. In 1992 and 1993, the meadow fescue canopies were cut at about monthly intervals, whereas in 1994 and 1995 they were cut each time the leaf area index (LAI) of the stand reached a value of 5 , as measured with an automatic LAI meter (Licor, USA). This resulted in a different number of cuts in each treatment during the second growing season of the grass in 1995 (Hakala and Mela 1996).

\section{Elevation of temperature and $\mathrm{CO}_{2}$ level}

As a means of raising the temperature above ambient, a greenhouse $(20 \mathrm{~m} \times 30 \mathrm{~m})$ was built over part of the experimental field (Hakala et al. 1996). The greenhouse temperatures were regulated during the whole year so that they were $3^{\circ} \mathrm{C}$ higher than the temperatures in the open field. The experimental field outside the greenhouse, at ambient temperature (referred to later as the open field), was covered at a height of 3$4 \mathrm{~m}$ with the same plastic film that was used in the construction of the greenhouse in order to achieve radiation and precipitation conditions comparable to those in the greenhouse. Even though the plastic film reduced the incoming photosynthetically active radiation (wavelength $400-700 \mathrm{~nm}$ ) by $40 \%$, the photon flux density under it remained well above the saturating level for photosynthesis (above $1000 \mu \mathrm{mol}$ photons $\mathrm{m}^{-2} \mathrm{~s}^{-1}$ ) during sunny days. To simulate real future conditions of warmer climate, the crops were sown inside the greenhouse about three weeks earlier than in the open field. Since the air temperatures rose steadily from April to July, the mean temperatures experienced by wheat were not always higher in the elevated temperature treatment than in the ambient temperature treat-

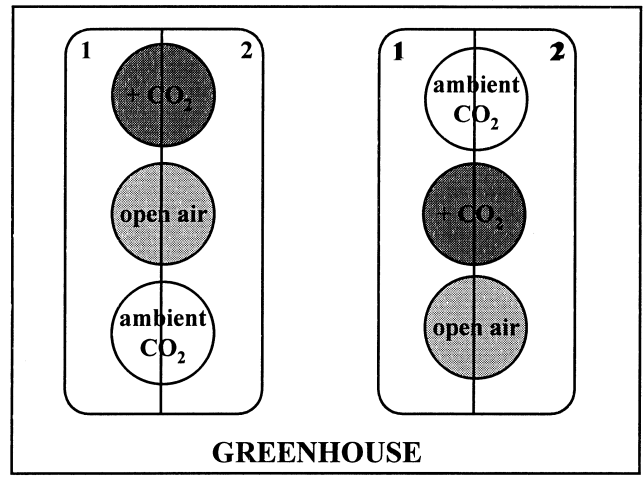

\section{Meadow fescue cv. Kalevi \\ 2. Spring wheat cv. Polkka}

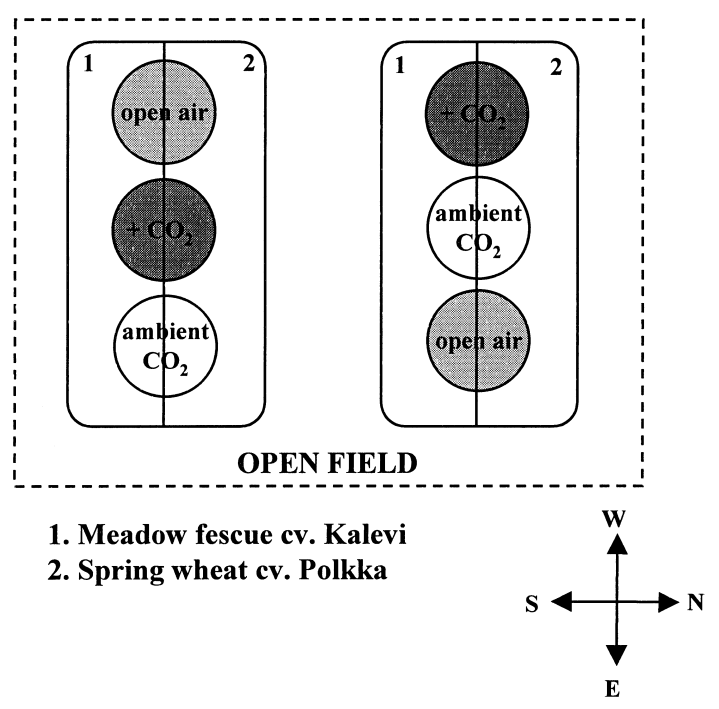

Fig. 1. Schematic presentation of the arrangement of experiments. For each temperature treatment there were two replicate open top chambers with ambient or elevated $\mathrm{CO}_{2}$ and two open air plots. The replicates were arranged in two rows, one on the northern side of the greenhouse or open field, the other one on the southern side.

ment at comparable developmental stages (Hakala et al. 1996, Hakala 1998). For meadow fescue, elevation of temperatures resulted in a longer growing season and thus higher total productivity, especially during the second growing seasons of the experiments (Hakala and Mela 1996).

All experiments were conducted in open-top chambers (OTCs) $3 \mathrm{~m}$ in diameter and $2 \mathrm{~m}$ high (Hakala et al. 1996). As shown in Fig. 1, each 


\section{AGRICULTURAL AND FOOD SCIENCE IN FINLAND}

\section{Hakala, K. et al. Photosynthesis and Rubisco kinetics under conditions of climate change}

OTC was divided into two parts. Spring wheat was sown in the northern half, while the other half was used for experiments with meadow fescue. Four OTCs were constructed in the greenhouse and four in the open field. In each place, two OTCs were maintained at elevated $\mathrm{CO}_{2}$ levels (target concentration $700 \mu \mathrm{ll}^{-1}, \mathrm{eCO}_{2}$ ) and two at ambient levels $\left(\mathrm{aCO}_{2}\right)$. The $\mathrm{CO}_{2}$ concentrations in the $\mathrm{eCO}_{2}$ treatments varied between 600 and $1000 \mu \mathrm{ll}^{-1}$ inside the greenhouse and between 550-800 $\mu 1 \mathrm{l}^{-1}$ in the open field (Hakala et al. 1996). Exceptionally during 1992, the $\mathrm{eCO}_{2}$ concentrations in the open field were at or slightly below $500 \mu \mathrm{l} \mathrm{l}^{-1}$ because the control of $\mathrm{CO}_{2}$ concentrations was not yet functioning well (Hakala et al. 1996). The $\mathrm{CO}_{2}$ concentrations were controlled with an automatic measuringdosing feedback system (Itumic OY, Jyväskylä, Finland), with a Siemens $\mathrm{CO}_{2}$ control device measuring the $\mathrm{CO}_{2}$ concentrations. The $\mathrm{CO}_{2}$ control device was calibrated periodically with pure nitrogen gas $\left(\mathrm{N}_{2}\right.$, zero-gas) and a gas mixture containing $1000 \mu \mathrm{l}$ of $\mathrm{CO}_{2} \mathrm{1}^{-1} \mathrm{~N}_{2}$. The calibration gases were supplied by AGA (Riihimäki, Finland). To allow evaluation of the chamber effect, the photosynthesis of the experimental plants inside the chambers was compared with that of plants growing on adjacent similarly shaped plots with no chamber (open air plots) both in the greenhouse and in the open field. The OTCs and open air plots were arranged in two rows in eastwest direction (Fig. 1), with one of the rows arranged on the southern side and the other one on the northern side. In both rows, the locations of the OTCs and open air plots were chosen randomly. The different rows are later referred to as replicates.

\section{Growth conditions}

The temperatures during the growing seasons 1992-1995 followed arbitrarily the long-term average (Finnish Meteorological Institute, Jokioinen observatory, 1961-1990), but the timing of the warm periods differed. May 1993 was warmer than average, while the rest of the growing season was either normal or cooler than aver- age. The 1994 growing season was exceptionally warm in July and the beginning of August. In 1995, the temperatures were exceptionally high for a few days at the end of May and beginning of June (Hakala and Mela 1996). As to radiation conditions, the 1993 growing season differed from the other seasons in the duration of sunshine: the total number of hours with full sunshine was only 172, 207 and 132 during the main months of crop growth, June, July and August, respectively. In 1994, the number of hours of full sunshine was 241, 422 and 210 in June, July and August, respectively. The weather conditions are explained in more detail in Hakala and Mela (1996) and in Hakala (1998).

During the first two growing seasons the experiments were conducted on a heavy clay soil mixed with $1000 \mathrm{~m}^{3} \mathrm{ha}^{-1}$ of peat containing $35 \%$ sand. In growing seasons 1994-1995, the claypeat soil of the experimental site was replaced with a lighter sandy loam soil brought from another field at Jokioinen. The soil nitrogen levels were adjusted to about $120 \mathrm{~kg} \mathrm{ha}^{-1}$ with a standard fertilizer $(20 \% \mathrm{~N}, 6 \% \mathrm{P}, 6 \% \mathrm{~K})$ during all growing seasons, both inside the greenhouse and in the open field (Hakala and Mela 1996). Drip irrigation was applied in 1992-1993 and manual irrigation in 1994-1995. Weeds were controlled with MCPA and metsulfuron-methyl, aphids with dimethoate and sulfotep, mildew with propiconazole, and fungi growing on meadow fescue during winter with prochloraz and quintozene.

\section{Measurements of net photosynthesis}

Net photosynthesis of the fully expanded flag leaves of wheat and of the youngest leaves of meadow fescue with completely emerged ligule was measured with a LCA-3-type $\mathrm{CO}_{2}$-analysis system with a narrow leaf Parkinson Leaf Chamber (PLC) (Analytical Development Company Ltd., Hoddesdon, UK). Net photosynthesis rates, stomatal conductances for water vapour and concentrations of $\mathrm{CO}_{2}$ in the sub-stomatal cavity were obtained from the LCA-3 analysis system, 
Vol. 8 (1999): 441-457.

calculated according to von Caemmerer and Farquhar (1981) (see manual of the LCA-3 device for equations). At each measuring time, the photosynthesis of 5-7 leaves was measured in each OTC. The measurements were conducted on sunny days, when the photon flux density was not lower than $800 \mu \mathrm{mol}$ photons $\mathrm{m}^{-2} \mathrm{~s}^{-1}$, which was found to be close to the light saturation for photosynthesis in both wheat and meadow fescue. About 30 min per OTC was required to measure the net photosynthesis and take samples from the measured leaves. Because the light intensities often varied during the same day, the photosynthesis was measured in replicate rows (all OTCs on the northern and southern sides of the greenhouse or open field), to ensure comparability of results between ambient and elevated OTCs. The two replicates were not always measured on the same day because of short duration of high light conditions. Because of low duration of sunshine, the photosynthesis measurements of wheat in 1993 were made for just one replicate row.

\section{Measurement of the content and activity of Rubisco}

The piece of the leaf where photosynthesis was measured was cut off after the measurement and immediately frozen in liquid nitrogen. The leaf samples were kept in liquid nitrogen until all leaves had been measured, and then they were stored at $-80^{\circ} \mathrm{C}$.

For enzyme assays, 4-5 leaf pieces collected in each OTC during the photosynthesis measurement were combined, ground in liquid nitrogen and homogenized in ice-cold $\mathrm{CO}_{2}$-free extraction buffer containing $10 \mathrm{mM} \mathrm{MgCl}{ }_{2}, 5 \mathrm{mM}$ DTT and $1 \mathrm{mM} \mathrm{Na}{ }_{2}$ EDTA in $100 \mathrm{mM}$ Tricine$\mathrm{NaOH}, \mathrm{pH}$ 8.2. The homogenate was centrifuged at $14000 \mathrm{rpm}$, at $+4^{\circ} \mathrm{C}$ for 2 minutes, and the supernatant was used for Rubisco determinations.

The total activity of Rubisco was measured spectrophotometrically by coupling $\mathrm{CO}_{2}$ fixation with NADH oxidation, which was observed as a decline of absorbance at $340 \mathrm{~nm}$ (Lilley and
Walker 1974). The reaction was initiated by adding $10-20 \mathrm{ml}$ of extract to a cuvette containing $430-440 \mathrm{ml}$ of the assay solution at room temperature. The final concentrations in the assay solution were $100 \mathrm{mM}$ Tricine- $\mathrm{NaOH}, \mathrm{pH} 8.2$, $8.8 \mathrm{mM} \mathrm{NaHCO}_{3}, 17.6 \mathrm{mM} \mathrm{MgCl}_{2}, 5.5 \mathrm{mM}$ ATP, $5 \mathrm{mM}$ phosphocreatine, 3.2 units of glyceraldehyde-3-phosphate dehydrogenase/ 3-phosphoglyceric phosphokinase, 3.2 units of creatine phosphokinase, $0.2 \mathrm{mM}$ NADH and $0.66 \mathrm{mM}$ RuBP. Before the assay, the extract containing the enzyme was incubated at room temperature in $10 \mathrm{mM} \mathrm{NaHCO}_{3}$ and $20 \mathrm{mM} \mathrm{MgCl}$ for 10 $\mathrm{min}$. The reagents in the assay were provided by Sigma Ltd.

For determination of the content of Rubisco, the protein was separated by SDS-PAGE (chemicals provided by Bio-Rad) by the modified Laemmli (1970) method, with 3.5\% stacking gel and $13 \%$ separating gel, and with purified spinach Rubisco (Sigma Ltd.) used as a standard. The amount of Rubisco in the gels was determined densitometrically after staining with $0.1 \%$ Coomassie Brilliant Blue R solution (Merck).

\section{Measurement of nitrogen content and specific leaf area of wheat flag leaves}

The nitrogen content ( $\%$ nitrogen of the dry weight) of the flag leaves of wheat was determined in 1992 with the Kjeldahl method using a Kjeltec System 1026 Distilling Unit (Tecator AB, Sweden), and with $\mathrm{CuSO}_{4} * 5 \mathrm{H}_{2} \mathrm{O}$ as the catalyst. In 1994 and 1995, the nitrogen content was determined with an automatic nitrogen analyser, LECO FP-428 (LECO corp., USA). The leaf area of the flag leaves was determined with a planimeter (Hayashi Denko, Japan). Specific leaf area was calculated from the leaf area and the dry weight of the leaves.

\section{Calculation and statistical testing of results}

For the overall comparison of photosynthetic 


\section{AGRICULTURAL AND FOOD SCIENCE IN FINLAND}

\section{Hakala, K. et al. Photosynthesis and Rubisco kinetics under conditions of climate change}

activity, stomatal conductance and sub-stomatal cavity $\mathrm{CO}_{2}$ concentration in the OTCs and on open air plots, all data from photosynthesis measurements were pooled over all the experimental years, though separately for the greenhouse and the open field. Data of senescing leaves of wheat (measurements conducted less than 20 days before yellow ripeness) were omitted from the comparison because senescence was found to affect photosynthesis dramatically, and the number of measurements of senescing leaves varied in the different treatments.

The enzyme measurements were made on combined leaf material of 4-5 leaves for which the photosynthesis had been measured. The photosynthesis rates, which are presented for the same sampling dates as the enzyme data, are means of the photosynthesis of the leaf samples used in the enzyme assays.

Differences in the results were examined by analysis of variance using the SAS Mixed procedure (SAS Institute, Inc. 1992). Data collected from the ambient and the elevated $\mathrm{CO}_{2}$ treatments during the same day were used for statistical tests. For the testing of the photosynthesis measurements, all data from each OTC were averaged over the whole growing season, and the average was treated as one observation. Statistical testing of differences in the $\mathrm{CO}_{2}$ treatments was done separately for greenhouse and open field material because there was only one greenhouse built to increase temperatures, and factors other than temperature could have had an effect on the results in the temperature treatments. For the same reason, it was not possible to test the significance of the differences between the two temperature treatments.

In the Mixed procedure, the $\mathrm{CO}_{2}$ treatment (ambient or enriched $\mathrm{CO}_{2}$ ) was analysed as the fixed effect, and the experimental year and the replicate (northern or southern row) were analysed as random effects. With two replicates per treatment, the number of observations used in the statistical testing of the photosynthesis data of wheat was 16 at elevated temperatures and 14 at ambient temperatures (only one replicate row was measured at ambient temperature in
1993). The photosynthesis of meadow fescue was first measured in 1993, and the number of observations was thus 12 for each temperature treatment. The Rubisco content and activity data were collected only in 1993 and 1994, and for wheat only from one replicate in 1993. The number of observations was thus 8 for meadow fescue and 6 for wheat for each temperature treatment. Because meadow fescue stands from 1993 and 1994 are not comparable (1993 was the second growing season, 1994 the first growing season), the real number of independent observations was 4 . Statistical testing of the results was not possible, therefore, because of the low degree of freedom. Instead, all data from all measurements of Rubisco and photosynthesis of the same material are presented in the figures.

\section{Results}

\section{Average photosynthetic activity and stomatal conductance}

The photosynthetic activity of spring wheat flag leaves and of meadow fescue leaves was on average $31-37 \%$ higher in $\mathrm{eCO}_{2}$ than in $\mathrm{aCO}_{2}$ at both ambient and elevated temperatures (Fig. 2). The difference in the activity was significant for both wheat $(\mathrm{P}=0.007$ at ambient temperatures and $\mathrm{P}=0.001$ at elevated temperatures) and meadow fescue $(\mathrm{P}=0.001$ at ambient temperatures and $\mathrm{P}=0.002$ at elevated temperatures). The photosynthetic activity in $\mathrm{aCO}_{2}$ was similar to that in the open air plots (Fig. 2).

The stomatal conductance of wheat was on average $23 \%$ and $27 \%$ and that of meadow fescue $28 \%$ and $36 \%$ lower in $\mathrm{eCO}_{2}$ than in $\mathrm{aCO}_{2}$ in the ambient and elevated temperature treatments, respectively (Fig. 3). The stomatal conductance was higher in the greenhouse than in the open field. This was probably due to the higher rela- 
Vol. 8 (1999): 441-457.

\section{A Wheat}

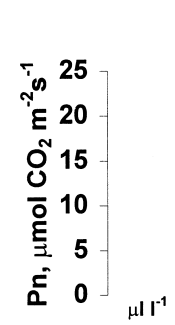

ambient temperatures

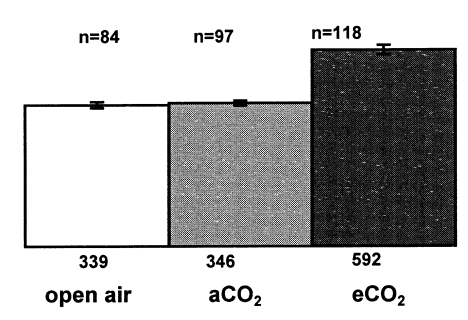

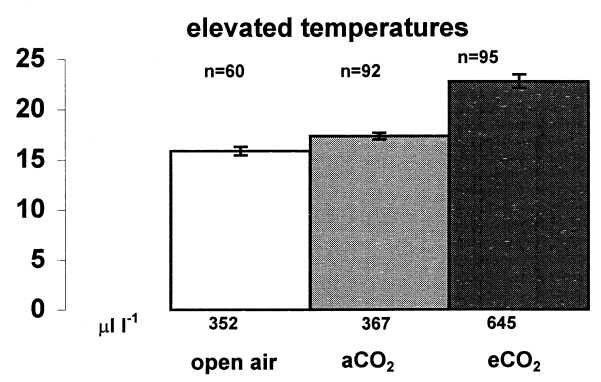

elevated temperatures

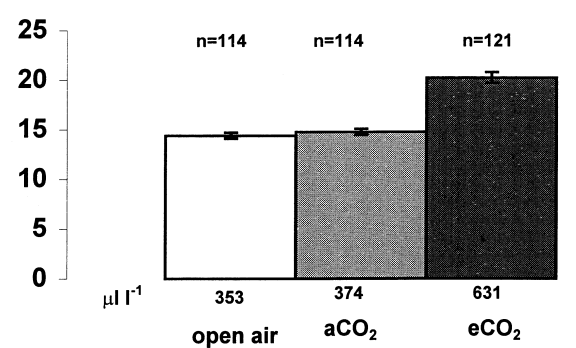

Fig. 2. Mean rates of photosynthesis of the flag leaves of spring wheat (Triticum aestivum L. cv. Polkka (A) and of leaves of meadow fescue (Festuca pratensis Hudson) cv. Kalevi (B) in open air plots, in open top chambers (OTCs) with ambient $\mathrm{CO}_{2}\left(\mathrm{aCO}_{2}\right)$ and in OTCs with elevated $\mathrm{CO}_{2}\left(\mathrm{eCO}_{2}\right)$, at ambient and elevated $\left(3^{\circ} \mathrm{C}\right.$ above ambient $)$ temperatures. Combined data from all measurements in 1992-1995. n=number of measured leaves. Average $\mathrm{CO}_{2}$ concentrations $\left(\mu 11^{-1}\right)$ at measuring time are shown below the columns. Bars on the columns indicate the standard error of mean. No data from measurements less than 20 days before yellow ripeness of wheat are included. Yellow ripeness was reached at elevated temperatures 85 , 95, 98 and 90 days after sowing and at ambient temperatures 101, 105, 97 and 102 days after sowing in 1992, 1993, 1994 and 1995 , respectively.

tive humidity in the greenhouse, especially in the OTCs (Hakala et al. 1996), because the stomatal conductance increases with the relative humidity (Grantz 1990). The substomatal cavity concentration of $\mathrm{CO}_{2}$ in wheat flag leaves was on average $75 \%$ (ambient temperatures) to $82 \%$ (elevated temperatures) and that of meadow fescue leaves $62 \%$ higher in $\mathrm{eCO}_{2}$ than in $\mathrm{aCO}_{2}$ (Fig. 4). The ratio of substomatal cavity $\mathrm{CO}_{2}$ concentration to ambient $\mathrm{CO}_{2}$ concentration was about 0.6 in wheat and from 0.6 (ambient temperatures) to 0.7 (elevated temperatures) in meadow fescue in all the $\mathrm{CO}_{2}$ treatments (open air, $\mathrm{aCO}_{2}$ and $\mathrm{eCO}_{2}$ ).

\section{Changes in photosynthetic activity and content and activity of Rubisco during the growing season}

The photosynthetic activity of the flag leaves of wheat and the leaves of meadow fescue was enhanced in $\mathrm{eCO}_{2}$ throughout the growing season (Fig. 5). Wheat photosynthesis declined 10-13 days before yellow ripeness in both $\mathrm{CO}_{2}$ treatments (for the dates of yellow ripeness, see legend of Fig. 2).

The content of Rubisco per leaf area of wheat flag leaves was about 3 to $4 \mathrm{~g} \mathrm{~m}^{-2}$ in 1993 and 
Hakala, K. et al. Photosynthesis and Rubisco kinetics under conditions of climate change

\section{A Wheat}
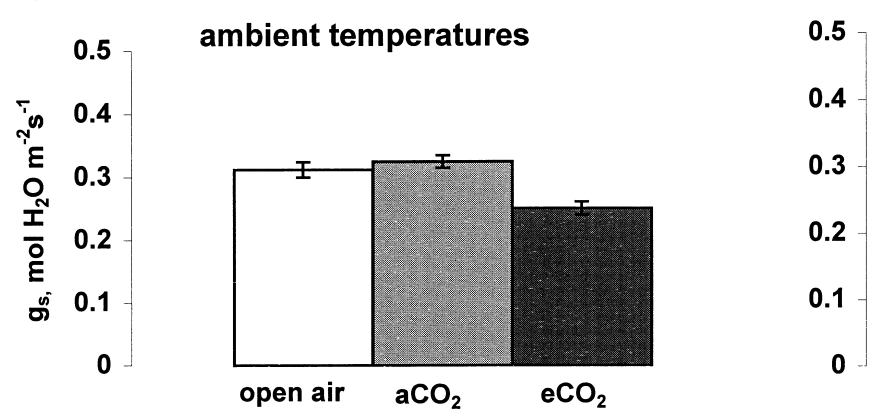

elevated temperatures

\section{B Meadow fescue}
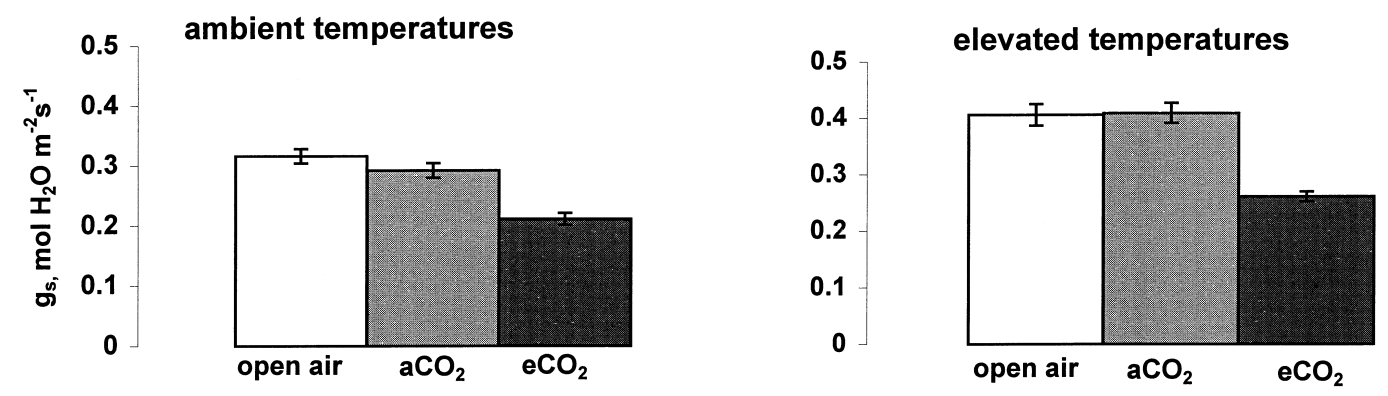

Fig. 3. Stomatal conductance $\left(\mathrm{g}_{\mathrm{s}}\right)$ of water vapour of the flag leaves of spring wheat (Triticum aestivum L.) cv. Polkka (A) and of leaves of meadow fescue (Festuca pratensis Hudson) cv. Kalevi (B) grown in open air plots, in open top chambers (OTCs) with ambient $\mathrm{CO}_{2}\left(\mathrm{aCO}_{2}\right)$ and in OTCs with elevated $\mathrm{CO}_{2}\left(\mathrm{eCO}_{2}\right)$, at ambient and elevated $\left(3^{\circ} \mathrm{C}\right.$ above ambient) temperatures. Combined data of all measurements in 1992-1995. No data from measurements less than 20 days before yellow ripeness of wheat are included. Number of measured leaves and average $\mathrm{CO}_{2}$ concentrations at measuring time are the same as in Fig. 2. Bars on the columns indicate the standard error of mean.

about 2 to $3 \mathrm{~g} \mathrm{~m}^{-2}$ in 1994 (Fig. 6a). It was lower in $\mathrm{eCO}_{2}$ than in $\mathrm{aCO}_{2}$, especially after anthesis, except at elevated temperatures in 1993 when there was no effect of $\mathrm{CO}_{2}$ enrichment on the content of Rubisco (Fig. 6a). The total activity of Rubisco in wheat flag leaves varied between 90 and $120 \mu \mathrm{mol} \mathrm{CO} \mathrm{Cm}^{-2} \mathrm{~s}^{-1}$. In general it was lower in plants grown in $\mathrm{eCO}_{2}$ (Fig. 7a), again except in 1993 at elevated temperatures, when there was no change. When the wheat leaves began to senesce about 10-13 days before yellow ripeness, both the content and the activity of Rubisco decreased sharply in both $\mathrm{CO}_{2}$ treatments.

The content of Rubisco in meadow fescue leaves was lower than in wheat, about $2-3 \mathrm{~g} \mathrm{~m}^{-2}$ in 1993 and about $1-1.5 \mathrm{~g} \mathrm{~m}^{-2}$ in 1994 (Fig. 6b). Despite the lower content of Rubisco in 1994, the total activity was the same in the two years, about 55-70 $\mu \mathrm{mol} \mathrm{CO} \mathrm{m}^{-2} \mathrm{~s}^{-1}$ (Fig. 7b). Both the content and the activity of Rubisco in meadow fescue leaves varied during the growing season, but there was no clear connection with the $\mathrm{CO}_{2}$ treatment.

\section{Nitrogen content and specific leaf area of flag leaves of wheat at anthesis}

The nitrogen content of wheat flag leaves at anthesis was lower in $\mathrm{eCO}_{2}$ than in $\mathrm{aCO}_{2}$ in both temperature treatments. The specific leaf area of 
Vol. 8 (1999): 441-457.

\section{A Wheat}

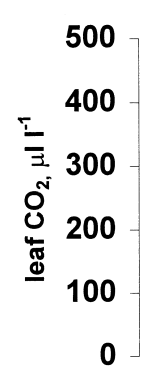

ambient temperatures

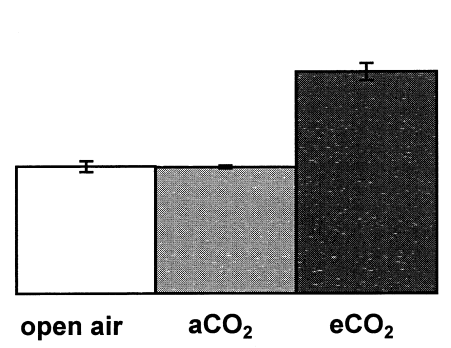

\section{B Meadow fescue}

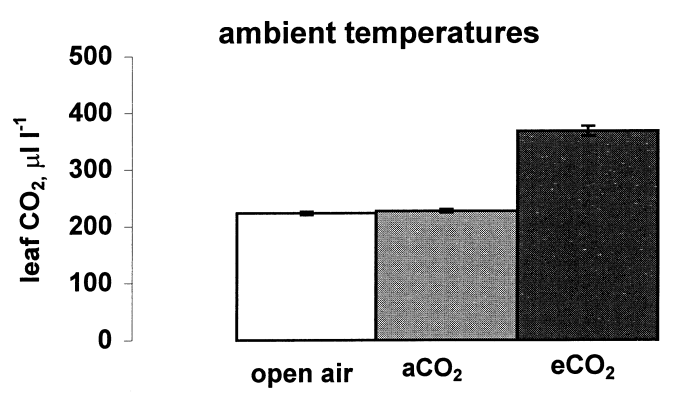

elevated temperatures
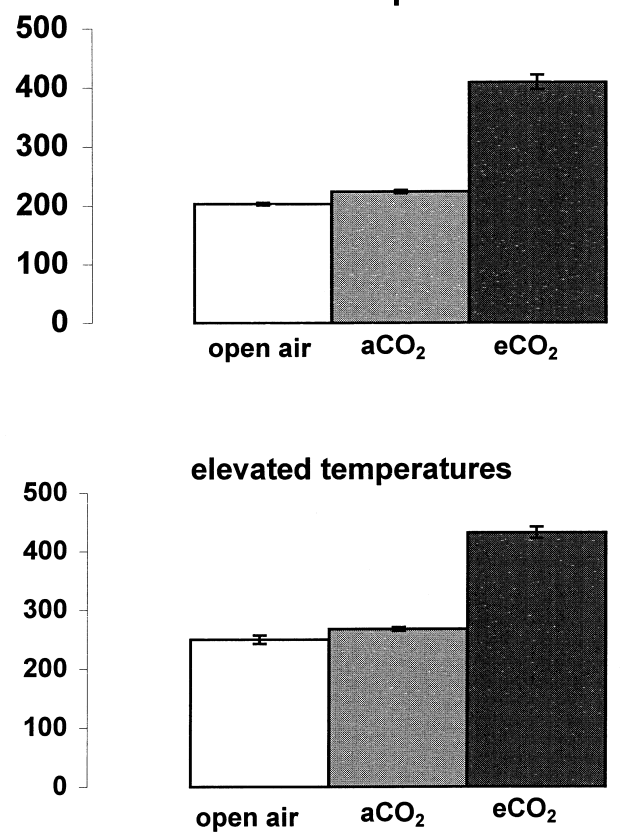

Fig. 4. Sub-stomatal cavity (=leaf) $\mathrm{CO}_{2}$ concentration $\left(\mu \mathrm{l} \mathrm{l}^{-1}\right)$ of the flag leaves of spring wheat (Triticum aestivum L.) cv. Polkka (A) and of leaves of meadow fescue (Festuca pratensis Hudson) cv. Kalevi (B) grown in open air plots, in open top chambers (OTCs) with ambient $\mathrm{CO}_{2}\left(\mathrm{aCO}_{2}\right)$ and in OTCs with elevated $\mathrm{CO}_{2}\left(\mathrm{eCO}_{2}\right)$, at ambient and elevated $\left(3^{\circ} \mathrm{C}\right.$ above ambient) temperatures. Combined data of all measurements in 1992-1995. No data from measurements less than 20 days before yellow ripeness of wheat are included. Number of measured leaves and average $\mathrm{CO}_{2}$ concentrations at measuring time are the same as in Fig. 2. Bars on the columns indicate the standard error of mean.

the flag leaves was greater in $\mathrm{eCO}_{2}$ than in $\mathrm{aCO}_{2}$ (Table 1).

\section{Discussion}

The photosynthesis of both wheat and meadow fescue was enhanced in $\mathrm{eCO}_{2}$ throughout the growing season at both ambient and elevated temperature treatments (Fig. 5). The reason for the lack of adaptation of photosynthesis in elevated $\mathrm{CO}_{2}$ in these experiments may be that the growth of the crops was potentially unrestricted. In a review of 34 previous studies, Sage
(1994) found that if the pot was large enough or the crops were, like ours, sown in a field, the photosynthesis in elevated $\mathrm{CO}_{2}$ was continually enhanced relative to ambient $\mathrm{CO}_{2}$. Sage (1994) was led to postulate that the most beneficial adaptation strategy to growth in $\mathrm{CO}_{2}$ enrichment would be a reduction in the amount and activity of Rubisco and an enhancement in the capacity for end product utilization. Enhancement in the end product utilization capacity is expressed as an increase in the rate of photosynthesis at high $\mathrm{CO}_{2}$ concentrations in plants acclimated to grow in these high concentrations (Sage et al. 1989, Sage 1994). In the present experiment, wheat Rubisco content and activity decreased in $\mathrm{CO}_{2}$ enrichment in 1994 in both temperature treat- 
Hakala, K. et al. Photosynthesis and Rubisco kinetics under conditions of climate change

A

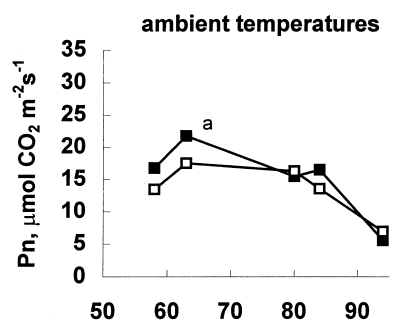

$\begin{array}{lllll}50 & 60 & 70 & 80 & 90\end{array}$
1993

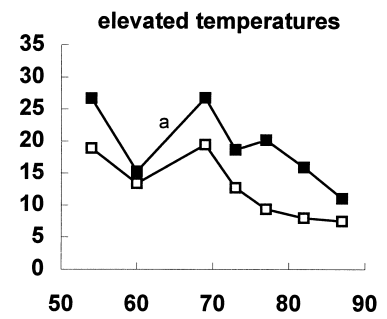

1994
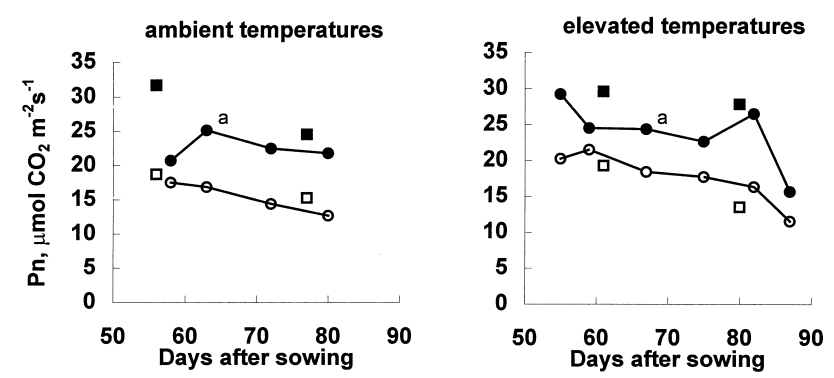

B

1993
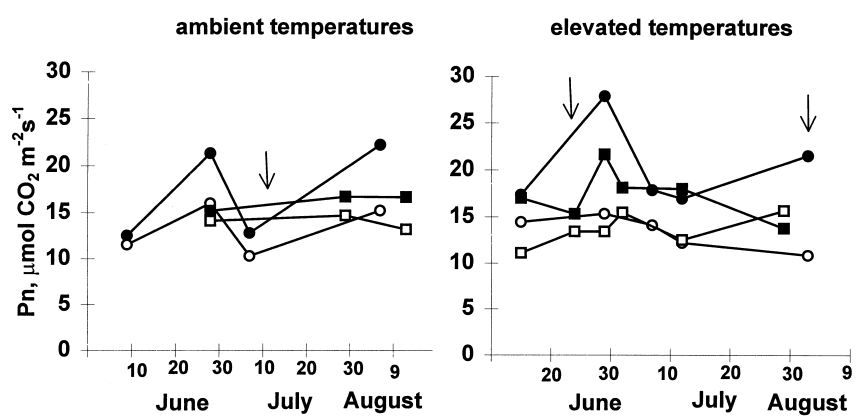

1994
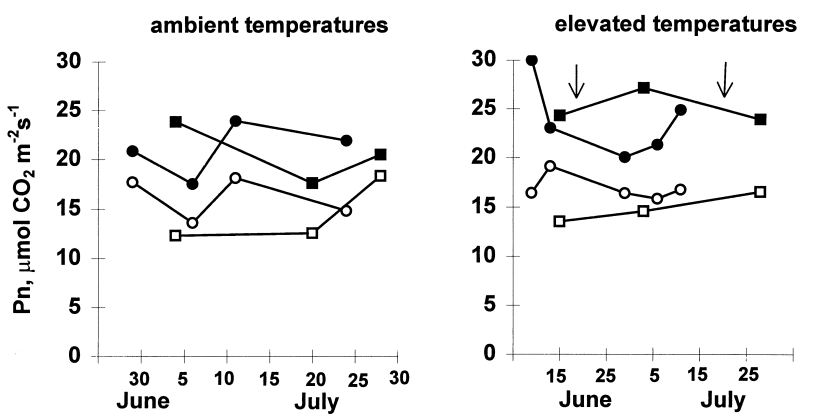

Fig. 5. Photosynthesis of the flag leaves of spring wheat (Triticum aestivum L.) cv. Polkka (A) and of leaves of meadow fescue (Festuca pratensis Hudson) cv. Kalevi (B) grown and measured in open top chambers (OTCs) with ambient $\mathrm{CO}_{2}$ (open symbols) and in OTCs with elevated $\mathrm{CO}_{2}$ (filled symbols) at ambient and elevated ( $3^{\circ} \mathrm{C}$ above ambient) temperatures in 1993 and 1994. OTCs were treated as replicates: replicate I, squares; replicate II, circles. $\mathrm{a}=$ anthesis. Arrows indicate the time of cutting of meadow fescue. 
Vol. 8 (1999): 441-457.

A

B

Fig. 6. Rubisco content of the flag leaves of spring wheat (Triticum aestivum L.) cv. Polkka (A) and of leaves of meadow fescue (Festuca pratensis Hudson) cv. Kalevi (B) grown in open top chambers (OTCs) with ambient $\mathrm{CO}_{2}$ (open symbols) and in OTCs with elevated $\mathrm{CO}_{2}$ (filled symbols) at ambient and elevated $\left(3^{\circ} \mathrm{C}\right.$ above ambient) temperatures in 1993 and 1994. OTCs were treated as replicates: replicate I, squares; replicate

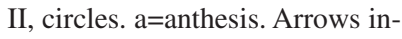
dicate the time of cutting of meadow fescue. For easier reading, the scale in (B) is adjusted according to the Rubisco content and is thus different in the figures for 1993 and 1994.

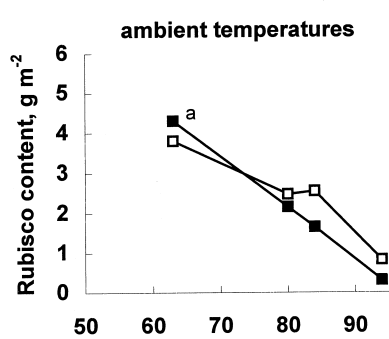

1994
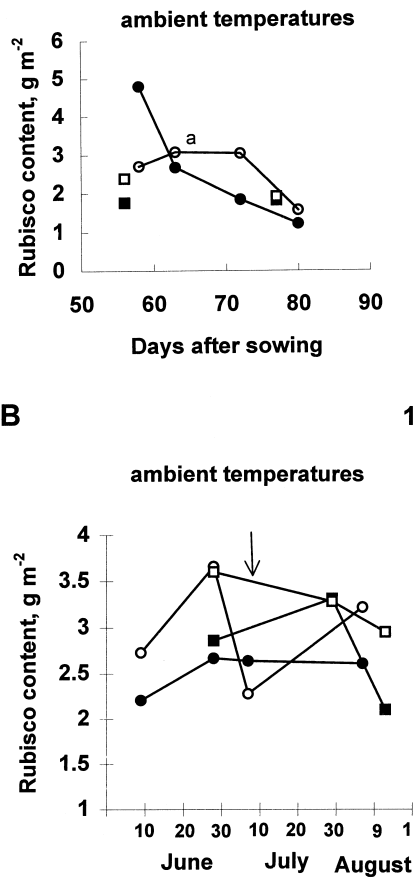

1993
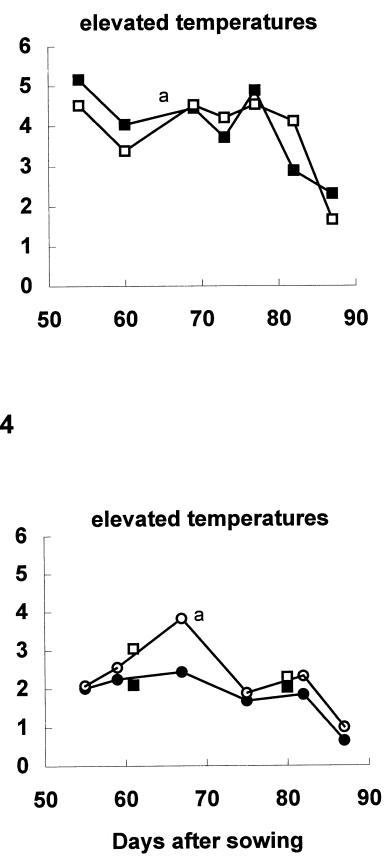

1993

elevated temperatures

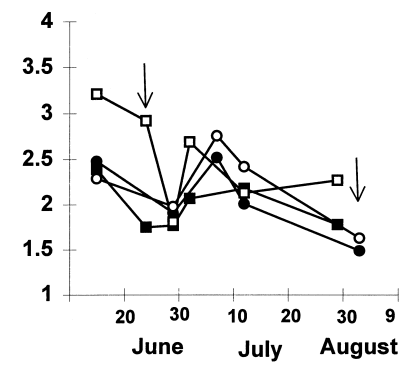

1994

ambient temperatures

elevated temperatures
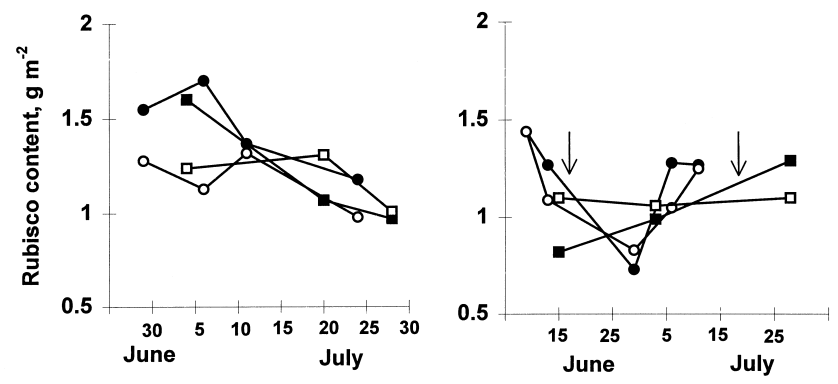
Hakala, K. et al. Photosynthesis and Rubisco kinetics under conditions of climate change

A

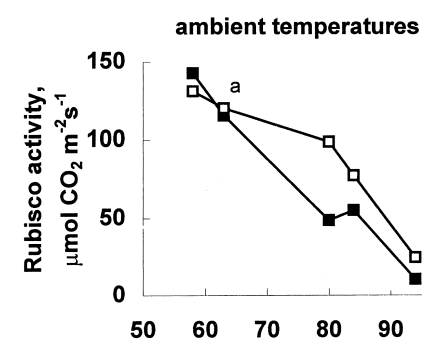

1993

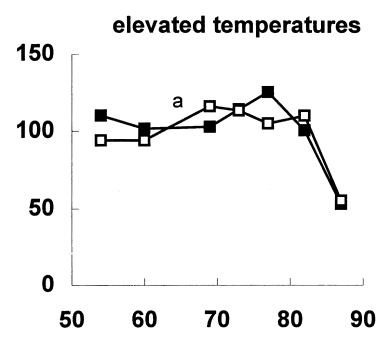

1994
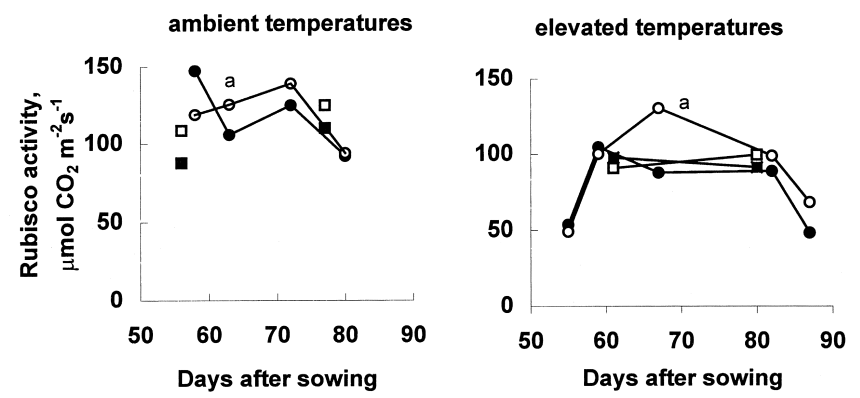

B

1993
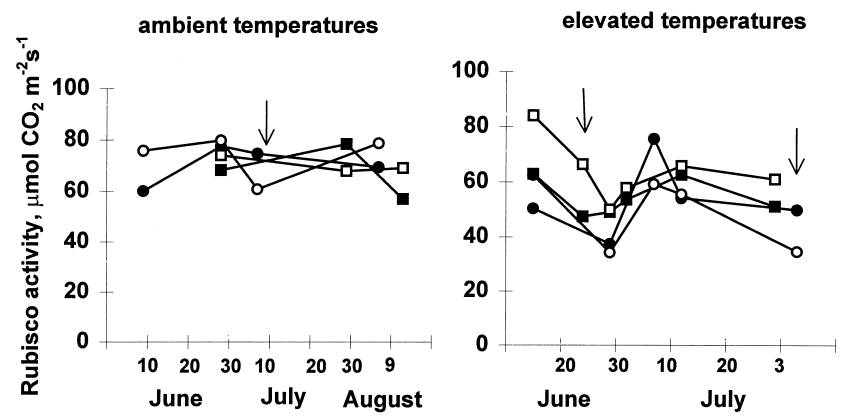

1994

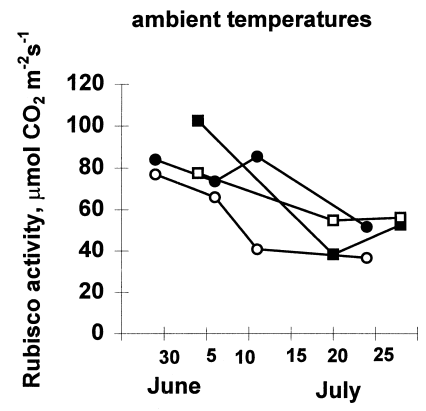

Fig. 7. Rubisco total activity of the flag leaves of spring wheat (Triticum aestivum L.) cv. Polkka (A) and of leaves of meadow fescue (Festuca pratensis Hudson) cv. Kalevi (B) grown in open top chambers (OTCs) with ambient $\mathrm{CO}_{2}$ (open symbols) and in OTCs with elevated $\mathrm{CO}_{2}$ (filled symbols) at ambient and elevated $\left(3^{\circ} \mathrm{C}\right.$ above ambient) temperatures in 1993 and 1994. OTCs were treated as replicates: replicate I, squares; replicate II, circles. $\mathrm{a}=$ anthesis. Arrows indicate the time of cutting of meadow fescue. 
Vol. 8 (1999): 441-457.

Table 1. Nitrogen content and specific leaf area (SLA) of spring wheat (Triticum aestivum L cv. Polkka) flag leaves at anthesis in 1992, 1994 and 1995 at Jokioinen, Finland, in different temperature (T) and CO$_{2}$ treatments ( $\mathrm{e}=$ elevated, $\mathrm{a}=$ ambient). The values of nitrogen content and SLA were calculated as an average for each open top chamber (OTC) separately, and the values presented here are averages of the values for two parallel OTCs $(n=2, \pm$ SEM). The average number of flag leaves used in the measurements of one OTC was 42, 81 and 78 in 1992, 1994 and 1995, respectively.

\begin{tabular}{lcccc}
\hline & $\mathrm{aT}, \mathrm{aCO}_{2}$ & $\mathrm{aT}, \mathrm{eCO}_{2}$ & $\mathrm{eT}, \mathrm{aCO}_{2}$ & $\mathrm{eT}, \mathrm{eCO}_{2}$ \\
\hline $\begin{array}{l}\text { Nitrogen content } \\
\text { (\% of dry weight) }\end{array}$ & & & \\
1992 & & & & \\
1994 & $4.07 \pm 0.24$ & $4.13 \pm 0.23$ & $4.55 \pm 0.08$ & $4.47 \pm 0.18$ \\
1995 & $4.71 \pm 0.15$ & $4.41 \pm 0.24$ & $4.59 \pm 0.25$ & $4.45 \pm 0.25$ \\
SLA offlag leaf & $3.19 \pm 0.37$ & $4.59 \pm 0.02$ & $4.28 \pm 0.00$ \\
$\left(\mathrm{~cm}^{2} \mathrm{~g}^{-1}\right)$ & & & \\
1992 & & & & \\
1994 & $254 \pm 2$ & $266 \pm 3$ & $248 \pm 7$ & $291 \pm 13$ \\
1995 & $274 \pm 6$ & $280 \pm 5$ & $292 \pm 12$ & $317 \pm 6$ \\
\hline
\end{tabular}

ments and in 1993 at ambient temperatures (Figs. $6 \mathrm{a}$ and $7 \mathrm{a})$. The photosynthesis was nevertheless enhanced in $\mathrm{eCO}_{2}$ throughout both growing seasons (Fig. 5a). It seems likely therefore that the wheat plants had adopted a beneficial acclimation strategy for growth in $\mathrm{CO}_{2}$ enrichment, comparable to that of the "good acclimators" in Sage's study (1994). There was no evidence of decreased Rubisco content in the leaves of meadow fescue, however.

It has been suggested that the decrease in Rubisco content as well as in the content of other Calvin cycle enzymes in elevated $\mathrm{CO}_{2}$ is due to accumulation of carbohydrates in the leaves (Stitt 1991, McKee and Woodward 1994). This kind of regulation would maintain a balance between carbon assimilation and the utilization of the assimilation products. Young, still growing leaves of plants are themselves sinks and have been found to acclimate less than older leaves in elevated $\mathrm{CO}_{2}$ (Stitt 1991, Nie et al. 1995). In line with this, a reduction in the Rubisco content associated with an increase in the carbohydrate levels has been observed in fully developed leaves in elevated $\mathrm{CO}_{2}$ (Bowes 1991, Stitt 1991, McKee and Woodward 1994, Rogers et al. 1998). Increased acclimation to elevated $\mathrm{CO}_{2}$ with the ageing of leaves was also seen in the present experiments: the Rubisco content of wheat flag leaves tended not to decrease in $\mathrm{CO}_{2}$ enrichment until anthesis or after (Fig. 6a). That this kind of adaptation was not observed in meadow fescue leaves was probably a result of the regular cuttings, which kept the leaf material relatively young throughout the growing season.

It may be that the Rubisco content does not decrease in elevated $\mathrm{CO}_{2}$ if the sink strength is in balance with the photosynthetic activity. This mechanism has been demonstrated in experiments with soybean (Campbell et al. 1988, 1990), wheat (Delgado et al. 1994, McKee and Woodward 1994) and perennial ryegrass (Rogers et al. 1998) and was at work in the present experiments as well. With meadow fescue, the lack of effect of $\mathrm{eCO}_{2}$ on Rubisco can be explained by the regular cuts providing for an unlimited sink for photosynthetic products. The effect of sink size could also be seen in our wheat experiments. In 1994, when there was a substantial increase in the photosynthetic rate in $\mathrm{eCO}_{2}$ (Fig. 5a), but only a small increase in plant biomass and yield (Hakala 1998), the Rubisco content was clearly decreased (Fig. 6a). In 1993, in turn, when the assimilation rate was clearly increased in $\mathrm{eCO}_{2}$ at elevated temperatures (Fig. 5 a) and there was also a substantial increase in 


\section{AGRICULTURAL AND FOOD SCIENCE IN FINLAND}

\section{Hakala, K. et al. Photosynthesis and Rubisco kinetics under conditions of climate change}

the biomass and yield (Hakala 1998), there was no clear effect of $\mathrm{CO}_{2}$ on the Rubisco content and activity (Figs. 6a and 7a). Apparently in 1993, when light conditions were not favourable during grain filling, the sinks were not filled in $\mathrm{aCO}_{2}$, and even in $\mathrm{eCO}_{2}$ there was still demand for photosynthetic products. In 1994, when radiation was at a high level, the sinks already would have filled more or less completely in $\mathrm{aCO}_{2}$.

Even though the Rubisco content and activity of wheat decreased, the photosynthesis increased in $\mathrm{CO}_{2}$ enrichment. This suggests that the effect of $\mathrm{CO}_{2}$ enrichment on photosynthesis was mainly brought about by a decrease in the rate of oxygenation of RuBP by Rubisco, and thus decreased photorespiration. The enzyme assays of Rubisco measured in a reaction mixture with saturating $\mathrm{CO}_{2}$ showed carboxylation velocities 3 to 10 times as high as the velocities of measured net photosynthesis of the same leaf material of both wheat and meadow fescue (Figs. 5 and 7). Evidently the potential velocity of carboxylation of Rubisco enzyme is much higher than the actual velocity in the present atmosphere. Increase in $\mathrm{CO}_{2}$ concentration would therefore increase the rate of net $\mathrm{CO}_{2}$ assimilation, even with substantial decrease in the content of Rubisco. If the amount of nitrogen bound in Rubisco were to decrease and be invested in sink growth, the carbon assimilation of the source leaves would also be less likely to be restricted by inhibition of triose phosphate utilization (Sharkey 1985, Stitt 1991). With elevated $\mathrm{CO}_{2}$ concentrations, ATP and NADPH would be released from the photorespiratory processes and would thus be available for RuBP regeneration.

The decrease in the Rubisco concentration observed in the flag leaves of wheat in the present experiment probably contributed to the decrease in the nitrogen content of wheat leaves measured at anthesis (Table 1). Because the specific leaf area of the flag leaves was not decreased, but rather increased, the decrease in the nitrogen levels was real and not a result of dilution with carbohydrate, as reported for some experiments (Campbell et al. 1988, Lawlor and Mitchell 1991). Wheat uses the nitrogen of its leaves, in particular its flag leaves, as material for protein in the grain (Waters et al. 1980, Lawlor et al. 1989). Decreased nitrogen content in the flag leaves may therefore result in a lower content of nitrogen in the grain, and deterioration in the baking quality of the flour milled from the grain (Finney and Barmore 1948). Grain nitrogen of the wheat plants of the present experiment was also decreased in $\mathrm{eCO}_{2}$ (Hakala 1998), which may have reduced the quality of the grain yield. Acclimation to elevated $\mathrm{CO}_{2}$ concentration might therefore reduce the quality of crops unless the nitrogen content of the plant is improved through increased fertilization.

The stomatal conductance to water vapour of both wheat and meadow fescue decreased in $\mathrm{eCO}_{2}$, in agreement with other investigations (Bowes 1991, Conroy et al. 1994, Sage 1994, Pearson et al. 1995). However, the calculated concentration of $\mathrm{CO}_{2}$ inside the leaves was about $75-82 \%$ and $60 \%$ higher in $\mathrm{eCO}_{2}$ than in $\mathrm{aCO}_{2}$ in wheat and meadow fescue, respectively (Figs. 3 and 4). Thus, plants growing in an environment with higher $\mathrm{CO}_{2}$ concentration will evaporate less water through the stomata and benefit from the elevated $\mathrm{CO}_{2}$ not only as an increased substrate for photosynthesis, but also through an improved efficiency in water use. This may be important for crop production in the future if the climate becomes warmer and water availability decreases.

The increase in photosynthesis in $\mathrm{eCO}_{2}$ was approximately the same in the two temperature treatments. This result seems contradictory to earlier reports of greater enhancement of photosynthesis at higher temperatures (von Caemmerer and Farquhar 1981, Cure and Acock 1986, Conroy et al. 1994). However, the temperature treatment in this experiment was designed to simulate future conditions, not to test the temperature effect per se. In order to simulate the real situation in a warmer climate, the crops were sown about three weeks earlier in the greenhouse. The temperatures experienced by the plants, especially wheat, were thus not always 
Vol. 8 (1999): 441-457.

higher in the greenhouse than in the open field at comparable developmental stages (Hakala et al. 1996, Hakala 1998). Moreover, the experiments at different temperatures are complicated by the fact that the conditions inside the greenhouse differed from those in the open field not only as to temperature but also as to relative humidity (Hakala et al. 1996). Higher relative humidity inside the greenhouse, especially in the OTCs, probably was the reason for higher stomatal conductances in the OTCs in the greenhouse (Grantz 1990). The higher stomatal conductance, in turn, may have contributed to the slightly higher average rates of photosynthesis observed in the greenhouse. In addition, with only one greenhouse to test the temperature effects, differences in factors such as soil structure may have been at work. Even though statistical testing of the effects of the possible warmer climate on photosynthesis was not possible, the results provide evidence for a seasonlong increase in photosynthesis in elevated $\mathrm{CO}_{2}$ in both the present and the future warmer climate. In a warmer climate, the growing season would be longer (Carter 1998), and grasses like meadow fescue would grow for a longer time and benefit more from the increased $\mathrm{CO}_{2}$ concentrations. If the growing season does become longer in the future, new more productive varieties of wheat with a higher sink capacity could be taken into cultivation, thereby reducing the risk of limitation of photosynthesis by insufficient sink.

\section{Conclusions}

Increased concentration of $\mathrm{CO}_{2}$ in the atmosphere is beneficial for both wheat and meadow fescue through an increase in the rate of photosynthesis and lower transpiration rates and thus increased efficiency of water use. In grasses like meadow fescue, biochemical acclimation of photosynthesis in elevated $\mathrm{CO}_{2}$ can be diminished by adjusting cuttings according to growth, thus bringing the sink size into better balance with the source. Increased nitrogen fertilization may be needed, however, to meet the higher demand for nitrogen with increased biomass accumulation. For wheat, increased nitrogen fertilization would help in increasing the nitrogen content of leaves and grain in conditions of increased $\mathrm{CO}_{2}$. However, in order to obtain full benefit from the increased concentration of $\mathrm{CO}_{2}$ and the resulting increased photosynthesis in the future atmosphere, new varieties of wheat with higher yield potential and greater potential sink size should be developed through breeding.

Acknowledgements. This work was part of the Finnish Research Programme on Climate Change (SILMU) and was supported, in part, by the Academy of Finland. The excellent technical assistance of Ms Leila Salo and Ms Marjo Vuorinen in determining the nitrogen contents of the samples and the invaluable help of M. Soc. Sci. Hannu Tuuri in the statistical testing of the results are gratefully acknowledged.

\section{References}

Bowes, G. 1991. Growth at elevated $\mathrm{CO}_{2}$ : photosynthetic responses mediated through Rubisco. Plant, Cell and Environment 14: 795-806.

Campbell, W.J., Allen, L.H., Jr. \& Bowes, G. 1988. Effects of $\mathrm{CO}_{2}$ concentration on rubisco activity, amount, and photosynthesis in soybean leaves. Plant Physiology 88: 1310-1316.

- , Allen, L.H., Jr. \& Bowes, G. 1990. Response of soybean canopy photosynthesis to $\mathrm{CO}_{2}$ concentration, light, and temperature. Journal of Experimental Botany 41: 427-433.
Carter, T.R. 1996. Developing scenarios of atmosphere, weather and climate for northern regions. Agricultural and Food Science in Finland 5: 235-249.

- 1998. Changes in the thermal growing season in Nordic countries during the past century and prospects for the future. Agricultural and Food Science in Finland 7: 161-179.

Conroy, J.P., Seneweera, S., Basra, A.S., Rogers, G. \& Nissen-Wooller, B. 1994. Influence of rising atmospheric $\mathrm{CO}_{2}$ concentrations and temperature on growth, yield and grain quality of cereal crops. Aus- 


\section{AGRICULTURAL AND FOOD SCIENCE IN FINLAND}

\section{Hakala, K. et al. Photosynthesis and Rubisco kinetics under conditions of climate change}

tralian Journal of Plant Physiology 21: 741-758.

Cure, J.D. \& Acock, B. 1986. Crop responses to carbon dioxide doubling: a literature survey. Agricultural and Forest Meteorology 38: 127-145.

Dalling, M.J., Boland, G. \& Wilson, J.H. 1976. Relation between acid proteinase activity and redistribution of nitrogen during grain development in wheat. Australian Journal of Plant Physiology 3: 721-730.

Delgado, E., Mitchell, R.A.C., Parry, M.A.J., Driscoll, S.P., Mitchell, V.J. \& Lawlor, D.W. 1994. Interacting effects of $\mathrm{CO}_{2}$ concentration, temperature and nitrogen supply on the photosynthesis and composition of winter wheat leaves. Plant, Cell and Environment 17: 12051213.

Finney, K.F. \& Barmore, M.A. 1948. Loaf volume and protein content of hard winter and spring wheats. Cereal Chemistry 5: 291-312.

Grantz, D.A. 1990. Plant response to atmospheric humidity. Plant, Cell and Environment 13: 667-679.

Hakala, K. 1998. Growth and yield potential of spring wheat in a simulated changed climate with increased $\mathrm{CO}_{2}$ and higher temperature. European Journal of Agronomy 9: 41-52.

- , Kaukoranta, T., Mela, T. \& Laurila, H. 1996. Arrangement of experiments for simulating the effects of elevated temperatures and elevated $\mathrm{CO}_{2}$ levels on fieldsown crops in Finland. Agricultural and Food Science in Finland 5: 25-47.

- \& Mela, T. 1996. The effects of prolonged exposure to elevated temperatures and elevated $\mathrm{CO}_{2}$ levels on the growth, yield and dry matter partitioning of fieldsown meadow fescue. Agricultural and Food Science in Finland 5: 285-298.

Hocking, P.J. \& Meyer, C.P. 1991. The effects of $\mathrm{CO}_{2}$ enrichment and nitrogen stress on growth, and partitioning of dry matter and nitrogen in wheat and maize. Australian Journal of Plant Physiology 18: 339-356.

IPCC 1996. Climate Change 1995: The Science of Climate Change. Contribution of WGI to the Second Assessment Report of the Intergovernmental Panel on Climate Change. Cambridge University Press, Cambridge. 572 p.

Laemmli, U.K. 1970. Cleavage of structural proteins during the assembly of the head of bacteriophage T4. Nature 227: 680-685.

Lawlor, D.W., Kontturi, M. \& Young, A.T. 1989. Photosynthesis by flag leaves of wheat in relation to protein, ribulose bisphosphate carboxylase activity and nitrogen supply. Journal of Experimental Botany 40: 43-52.

- \& Mitchell, A.C. 1991. The effects of increasing $\mathrm{CO}_{2}$ on crop photosynthesis and productivity: a review of field studies. Plant, Cell and Environment 14: 807818.

Leegood, R.C. 1993. The Calvin cycle and photorespiration. In: Lea, P.J. \& Leegood, R.C. (eds.). Plant Biochemistry and Molecular Biology. John Wiley \& Sons Ltd, Chichester. p. 27-45.

Lilley, R.McC. \& Walker, D.A. 1974. An improved spectrophotometric assay for ribulosebisphosphate carboxylase. Biochimica et Biophysica Acta 358: 226229.
McKee, I.F. \&Woodward, F.I. 1994. The effect of growth at elevated $\mathrm{CO}_{2}$ concentrations on photosynthesis in wheat. Plant, Cell and Environment 17: 853-859.

Nie, G.Y., Long, S.P., Garcia, R.L., Kimball, B.A., Lamorte, R.L., Pinter, P.J., Jr., Wall, G.W. \& Webber, A.N. 1995. Effects of free-air $\mathrm{CO}_{2}$ enrichment on the development of the photosynthetic apparatus in wheat, as indicated by changes in leaf proteins. Plant, Cell and Environment 18: 855-864.

Palta, J.A. \& Fillery, I.R.P. 1995. N application enhances remobilization and reduces losses of pre-anthesis $\mathrm{N}$ in wheat grown on a duplex soil. Australian Journal of Agricultural Research 46: 519-531.

Pearson, M., Davies, W.J. \& Mansfield, T.A. 1995. Asymmetric responses of adaxial and abaxial stomata to elevated $\mathrm{CO}_{2}$ : impacts on the control of gas exchange by leaves. Plant, Cell and Environment 18: 837-843.

Quick, W.P., Fichtner, K., Schulze, E.-D., Wendler, R., Leegood, R.C., Mooney, H., Rodermel, S.R., Bogorad, L. \& Stitt, M. 1992. Decreased ribulose-1,5-bisphosphate carboxylase-oxygenase in transgenic tobacco transformed with "antisense" rbcS. IV. Impact on photosynthesis in conditions of altered nitrogen supply. Planta 188: 522-531.

Rogers, A., Fischer, B.U., Bryant, J., Frehner, M., Blum, H., Raines, C.A. \& Long, S.P. 1998. Acclimation of photosynthesis to elevated $\mathrm{CO}_{2}$ under low-nitrogen nutrition is affected by the capacity for assimilate utilization. Perennial ryegrass under free-air $\mathrm{CO}_{2}$ enrichment. Plant Physiology 118: 683-689.

Sage, R. 1994. Acclimation of photosynthesis to increasing atmospheric $\mathrm{CO}_{2}$ : The gas exchange perspective. Photosynthesis Research 39: 351-368.

- , Sharkey, T.D. \& Seemann, J.R. 1989. Acclimation of photosynthesis to elevated $\mathrm{CO}_{2}$ in five $\mathrm{C}_{3}$ species. Plant Physiology 89: 590-596.

SAS Institute, Inc. 1992. SAS technical report P-229, SAS/STAT software: changes and enhancements, release 6.07. SAS Institute, Inc., Carey/NC. 620 p.

Schmitt, M.R. \& Edwards, G.E. 1981. Photosynthetic capacity and nitrogen use efficiency of maize, wheat and rice: a comparison between $\mathrm{C}_{3}$ and $\mathrm{C}_{4}$ photosynthesis. Journal of Experimental Botany 32: 459-466.

Sharkey, T.D. 1985. Photosynthesis in intact leaves of $\mathrm{C}_{3}$ plants: physics, physiology and rate limitations. The Botanical Review 51: 53-105.

Stitt, M. 1991. Rising $\mathrm{CO}_{2}$ levels and their potential significance for carbon flow in photosynthetic cells. Plant, Cell and Environment 14: 741-762.

Waters, S.P., Peoples, M.B., Simpson, R.J. \& Dalling, M.J. 1980. Nitrogen redistribution during grain growth in wheat (Triticum aestivum L.). I. Peptide hydrolase activity and protein breakdown in the flag leaf, glumes and stem. Planta 148: 422-428.

von Caemmerer, S. \& Farquhar, G.D. 1981. Some relationships between the biochemistry of photosynthesis and the gas exchange of leaves. Planta 153: 376387.

Wong, S.C. 1979. Elevated atmospheric partial pressure of $\mathrm{CO}_{2}$ and plant growth. I. Interactions of nitrogen nutrition and photosynthetic capacity in $\mathrm{C}_{3}$ and $\mathrm{C}_{4}$ plants. Oecologia 44: 68-74. 
Vol. 8 (1999): 441-457.

\title{
SELOSTUS
}

\section{Kevätvehnän ja nurminadan fotosynteesi ja Rubisco-kinetiikka simuloidun ilmaston- muutoksen eli kohotetun hiilidioksidipitoisuuden ja kohotetun lämpötilan oloissa}

\author{
Kaija Hakala, Riitta Heliö, Eeva Tuhkanen ja Timo Kaukoranta \\ Maatalouden tutkimuskeskus ja Metsäntutkimuslaitos
}

Kevätvehnää (Triticum aestivum L. cv. Polkka) ja nurminataa (Festuca pratensis Hudson cv. Kalevi) kasvatettiin normaalissa ja kohotetussa $\left(700 \mathrm{ml} \mathrm{l}^{-1}\right)$ hiilidioksidissa sekä nykyisen keskilämpötilan oloissa että simuloidussa tilanteessa, jossa ilmasto on lämmennyt kolmella asteella. Lämpimämmän ilmaston simulointi tehtiin kasvihuoneessa, joka oli rakennettu koepaikkana toimivalle pellolle. $\mathrm{CO}_{2}$-pitoisuuksien säätöä varten sekä kohotetun hiilidioksidin $\left(\mathrm{eCO}_{2}\right)$ että verrokkina olevat normaalin $\mathrm{CO}_{2}: \mathrm{n}$ $\left(\mathrm{aCO}_{2}\right)$ kokeet tehtiin suurissa (läpimitta $3 \mathrm{~m}$ ) päältä avoimissa kammioissa. Sekä vehnän että nurminadan fotosynteesinopeus oli 31-37\% isompi eCO $\mathrm{e}_{2}$ :ssa kuin $\mathrm{aCO}_{2}$ :ssa koko kasvukauden ajan, joskin vehnällä ero $\mathrm{eCO}_{2}$ :n ja $\mathrm{aCO}_{2}$ :n välillä pieneni, kun fotosynteesiteho laski molemmissa käsittelyissä 10-13 päivää ennen keltatuleentumista. Ilmarakojen johtavuus oli molemmilla koekasveilla $23-36 \%$ pienempi $\mathrm{eCO}_{2}$ :ssa kuin $\mathrm{aCO}_{2}$ :ssa. Ribuloosi-1,5,-bisfosfaatti karboksylaasi-oksygenaasi (Rubisco) -entsyymin määrä ja aktiivisuus laskivat vehnällä $\mathrm{eCO}_{2}$ :ssa, paitsi kohotetun lämpötilan oloissa vuonna 1993, jolloin vehnän sato nousi selvästi $\mathrm{eCO}_{2}$ :ssa. Nurminadalla Rubiscon määrä ja aktiivisuus eivät riippuneet hiilidioksidikäsittelystä. Tulokset viittaavat siihen, että biokemiallista sopeutumista kohotettuun hiilidioksidiin tapahtuu vain, jos fotosynteesituotteille ei ole tarjolla riittävän suurta nielua (sink). Vehnän nielun kokoa voidaan kasvattaa jalostamalla uusia, runsassatoisia lajikkeita, jotka hyötyvät paremmin tulevaisuuden kohonneesta $\mathrm{CO}_{2}$-pitoisuudesta. Nurminadan nielukokoa voidaan säädellä leikkaamalla nurmea sen kasvua vastaavasti. 
AGRICULTURAL AND FOOD SCIENCE IN FINLAND 